Article

\title{
The Effect of Pervious Concrete on Water Quality Parameters: A Case Study
}

\author{
Brent S. Pilon, John S. Tyner*(D), Daniel C. Yoder and John R. Buchanan \\ Department of Biosystems Engineering and Soil Science, University of Tennessee, Knoxville, TN 37996, USA; \\ pilonbrent@gmail.com (B.S.P.); dyoder@utk.edu (D.C.Y.); jbuchan7@utk.edu (J.R.B.) \\ * Correspondence: jtyner@utk.edu; Tel.: +1-865-974-7130
}

Received: 12 December 2018; Accepted: 30 January 2019; Published: 2 February 2019

check for updates

\begin{abstract}
Stormwater is a leading source of pollutants that when transported to surface waters may damage aquatic habitat, decrease reservoir capacity, and contaminate drinking water. In order to evaluate whether a pervious concrete detention system can remove stormwater pollutants from the runoff, water quality was monitored at a site with both impervious asphalt and pervious concrete parking areas. The stormwater flowed across asphalt pavement before infiltrating into the pervious concrete and an aggregate sub-base below. The runoff was sampled exiting the asphalt but prior to entering the pervious concrete, and after it passed through the pervious concrete detention system, representing pre- and post-treatment sampling. Results showed statistically significant $(p<0.05)$ decreases in concentrations of total suspended solids, nitrite, chemical oxygen demand, and polycyclic aromatic hydrocarbons compared to untreated asphalt runoff. Zinc concentrations were apparently reduced, but not quite to statistically significant levels $(p=0.054)$. Values of $\mathrm{pH}$ and sulfate both showed statistically significant $(p<0.05)$ increases.
\end{abstract}

Keywords: stormwater; pervious pavement; pervious concrete; water quality

\section{Introduction}

Paved surfaces (pavements) are the most common structures built by man, occupying twice the area of buildings, and it is estimated that two-thirds of the precipitation falling on urban impervious surfaces falls on pavements [1]. From a hydrologic viewpoint, imperviousness alters the natural hydrology of a watershed by decreasing infiltration into the soil and increasing runoff volumes and flowrates. The increased volumes and flowrates reach receiving waters as high-energy concentrated flows that erode stream banks and scour stream beds, leading to increased stream sediment loads. Decreased infiltration also interferes with groundwater recharge, which significantly affects stream low flows as well, especially in drought conditions [2].

To address these negative hydrologic impacts of impervious paved surfaces, permeable pavements such as open-joint paving blocks, pervious asphalt, and pervious concrete which allow water and air to pass through them are being installed. Studies indicate that pervious concrete enables more efficient land usage compared to traditional collection, conveyance, and detention stormwater infrastructure because of its ability to serve as both a pavement and a runoff storage structure [3]. Pervious concrete typically has $20 \%$ voids and can infiltrate at a rate of $5-45 \mathrm{~m} / \mathrm{h}$ [4]. Sometimes concern is expressed that infiltrating runoff might create localized high water tables, but such fears seem generally unwarranted [5].

In addition to the hydrologic concerns described above, imperviousness negatively affects water quality. Urbanization increases impervious surfaces such as streets, driveways, roofs, parking lots and sidewalks on which pollutants such as sediment, debris, salts, fertilizers, and vehicle-based pollutants such as brake and tire dust and petroleum-based fluids are deposited. Additionally, urban pervious 
surfaces such as lawns are more likely to produce pollutants than are non-urban grassed areas [6]. All these pollutants remain on the surfaces until a precipitation event washes them into storm drains, which transports them to surface waters and potentially results in fish kills, habitat destruction, loss of aesthetic value, and drinking water contamination [7]. An investigation of the origins and amounts of toxic pollutants in urban stormwater found that runoff from vehicle service and parking areas had relatively high levels of suspended solids, metals, and hydrocarbons compared to runoff from roofs, streets, and landscaped areas [8]. Another study found that stormwater contains higher levels of solids, chemical oxygen demand, and other pollutants compared to rainwater [9]. A study of a major rural highway found high levels of suspended solids, chemical oxygen demand, metals, and hydrocarbons [10].

Though the nation's surface water quality has in many ways dramatically improved since the passage of the Clean Water Act and the National Pollutant Discharge Elimination System permitting program, many impaired water bodies still exist. According to the National Water Quality Inventory [11], prepared under sections 305(b) and 303(d) of the Clean Water Act, at least 9\% of the stream miles and $7 \%$ of the lake acres assessed were impaired by sediment and turbidity. At least $7 \%$ of the stream miles and $9 \%$ of the lake acres assessed were impaired by oxygen depletion, and at least $6 \%$ of the stream miles and $7 \%$ of the lake acres assessed were impaired by metals. Stormwater is listed as a leading contributor to these impairments because it transports both soluble pollutants and pollutants adsorbed to sediments.

Pervious concrete systems address the issue of pollutant delivery in two ways. If the stormwater is detained in temporary storage in a stone sub-surface basin, the sediment has more time to settle than if it were directly transported offsite by a traditional storm drain outlet. Secondly, if the system is designed for retention, at least some of the stormwater infiltrates into the underlying soil such that there is reduced runoff, and pollutants transported by the infiltrated water are filtered out by the underlying soil. Sandy soils will allow more runoff to infiltrate, but clay soils with higher cation exchange capacities will capture more pollutants [12].

The Stormwater Best Management Practice Report shows pervious pavement removal efficiencies for solids, nitrogen, and metals to be from $65 \%$ to $100 \%$ [13]. Infiltration best management practices such as permeable pavement retention systems are considered to be $100 \%$ effective at removing pollutants, since none of the discharge moves directly to surface waters. This may be somewhat overstated. Infiltration should provide significant pollutant removal such that as water infiltrates through the underlying soil layers, pollutants can adsorb to the soil matrix or be biodegraded by microorganisms. However, there is concern regarding the mobility of metals and hydrocarbons in soils, especially in coastal areas with very sandy soils, high infiltration rates, and potentially insufficient contact time for breakdown or adsorption of contaminants.

Soil lead concentrations decrease with both increasing distance from highways and soil depth near highways [14-17]. Similar results have been shown for zinc also [15]. These findings demonstrate why bio-immobilization and bioremediation are common practices in contaminated land remediation and oil spill cleanup, and indicate that infiltration areas associated with pervious pavements can provide similar effects.

Whereas there is a minor concern that the use of pervious pavements could result in groundwater contamination due to increased infiltration rates, there are two specific cases where this could potentially be a more severe problem. The first case is a brownfield where pollutant residue remains from previous land use, so enhanced infiltration would be more likely to flush that residue into groundwater and receiving streams. The second case is where the soil is so sandy or gravelly that it provides little treatment but rather acts as a conduit for untreated runoff to rapidly reach the deeper groundwater. Almost any other soil has enough capacity to filter out the hydrocarbons and fine particles transporting metals. Overall, infiltration will offer greater opportunity for stormwater remediation compared to direct conveyance to surface waters, and unless a community in a watershed 
is entirely dependent on shallow aquifers for their water supply, infiltration offers the best alternative for managing polluted stormwater.

The pervious pavements themselves provide a porous medium on which pollutants such as metals can potentially be immobilized due to the high surface area encountered by runoff as it infiltrates. Because the environment within the pavement is aerated and periodically moistened, an ecosystem similar to that found in wastewater trickling filters exists in the pavement such that hydrocarbons and other pollutants can be immobilized and degraded within the pavement. As long as automobiles continue to be manufactured as they are today, pollutants will continue to be deposited onto paved surfaces. These can either accumulate in surface waters or in pavements and soils where they can be immobilized and treated [1]. For example, a previous study measured the ability of pervious pavements to support microbial populations capable of degrading hydrocarbons using a laboratory pervious pavement system simulation [18]. They showed that with increased microbial populations, effluent oil and grease levels decreased to the point that only $2 \%$ of the oil applied to the system was recovered in the effluent. These studies demonstrate the mechanisms by which pervious pavements can treat infiltrated pollutants in manners similar to those of trickling filters or of native soils. A laboratory study of permeable pavers overlying subsurface storage undertaken at the University of Edinburgh found that the system decreased ammonia concentration while increasing nitrate concentrations due to nitrification that took place during treatment [19]. This same study also found that biochemical oxygen demand (BOD) decreased significantly.

At a site in Goldsboro, NC, measured runoff pollutant concentrations from an asphalt pavement were compared to the discharge concentrations of an adjacent permeable interlocking concrete paver (PICP) pavement consisting of $8 \mathrm{~cm}$ thick pavers placed over $8 \mathrm{~cm}$ of No. 72 stone pea gravel and $20 \mathrm{~cm}$ of No. 57 washed gravel [20]. The PICP discharge showed significant decreases in total Kjeldahl nitrogen, ammonium, total phosphorus, and zinc when compared to the asphalt runoff over 14 storm events. These results showed no significant changes in nitrate, nitrite, or total suspended solids. The Goldsboro study site was a paired watershed rather than a comparison of inflow versus outflow, so that pollutant loadings in the asphalt runoff had to be assumed equal to the loadings of water infiltrating the PICPs. A similar site in Swansboro, NC, installed over a sandy soil, yielded no runoff from the 16 storm events [20].

In a French study [21], the quality of pervious asphalt discharge from thirty rainfall events was compared to discharge from a nearby catchment drained by a traditional separate system over a period of four years. The pervious discharge showed lower concentrations of total suspended solids, lead, and zinc. The research also showed that metals were more concentrated in the pavement itself than at the geotextile membrane separating the underlying soils from the stone sub base, and metals concentrations were even lower in the underlying soil. A comparison of pollutant concentrations from a pervious asphalt pavement and a reference catchment draining the adjacent streets, sidewalks, and rooftops found reduced suspended solids, lead, and zinc concentrations from the pervious asphalt [22]. Another study monitored discharge from a French highway before and after the traditional asphalt road course was replaced by pervious asphalt and compared the water quality of the runoff [23]. The pervious pavement yielded decreases in total suspended solids, lead, zinc and hydrocarbons.

A comparison of runoff from a traditional asphalt pavement to the discharge from an adjacent permeable paver lot showed reduced concentrations of zinc over three storm events [24]. In a follow-up study at the same site conducted after six years of daily parking usage [25], decreases in zinc and hydrocarbons were shown in the paver discharge.

A comparison of pollutant concentrations from traditional asphalt and concrete pavements to a permeable pavement in Florida found decreases in suspended solids, nitrate, lead, and zinc between the asphalt and the permeable pavement, but no apparent differences between the traditional concrete and the permeable pavement [26]. Another study compared the quality of runoff from asphalt, permeable paver, and crushed stone driveways in Connecticut [27]. They found the highest concentrations of total suspended solids, nitrate, lead and zinc in the runoff from asphalt drives. 
Total suspended solids and zinc levels were much lower for the pavers than for the stone drives. Zinc has also been removed from stormwater passing through bioretention cells [28].

This research provided another case study evaluating the impact on stormwater quality from utilizing pervious concrete with sub-surface detention. To evaluate water quality impacts of the pervious treatment system, samples of runoff from asphalt parking spaces were collected (pre-treatment samples), along with runoff samples collected after water from the asphalt parking spaces passed through the pervious concrete with detention system (post-treatment). By sampling from a singular treatment train (pre- and post-) across multiple precipitation events, direct comparison of the effect of the treatment on the stormwater quality was possible. We hypothesized that remediation of the stormwater runoff would be enhanced by the combination of filtering, increased detention time, lower flowrates in the aggregate sub-base, and the biological, physical, and chemical properties represented in the pervious pavement system.

\section{Methods}

\subsection{Site Layout}

The monitoring study was conducted at the Alcoa City Center in Alcoa, TN, USA. (Figure 1). The site consists of asphalt driving lanes and parking (red text in figure) adjacent to a row of pervious concrete parking (green text in figure) on the down-gradient portion of the lot, with rock-based detention storage beneath the pervious concrete. The lot is sloped such that the majority of the runoff from the asphalt infiltrates through the pervious concrete and is temporarily stored in the underlying limestone aggregate reservoir (40\% porosity) before exiting through a $38 \mathrm{~cm}$ (15 in) diameter perforated French drain (Figure 2). The water exiting the drain enters a vault, then discharges to the city stormwater lines via a secondary outlet pipe leading from the vault. The asphalt entrance and exit drain offsite through unrelated outlets.

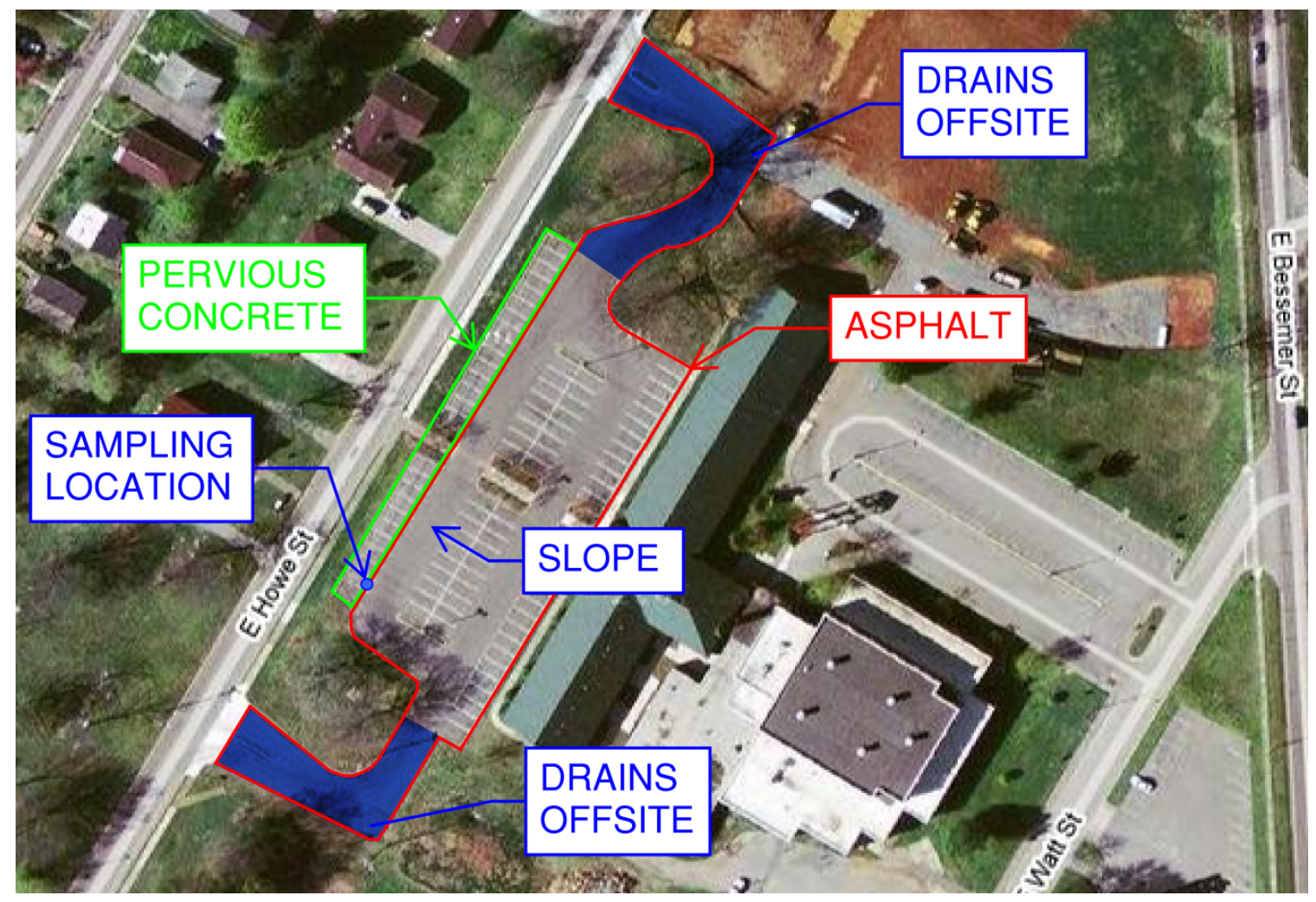

Figure 1. The Alcoa City Center site. 


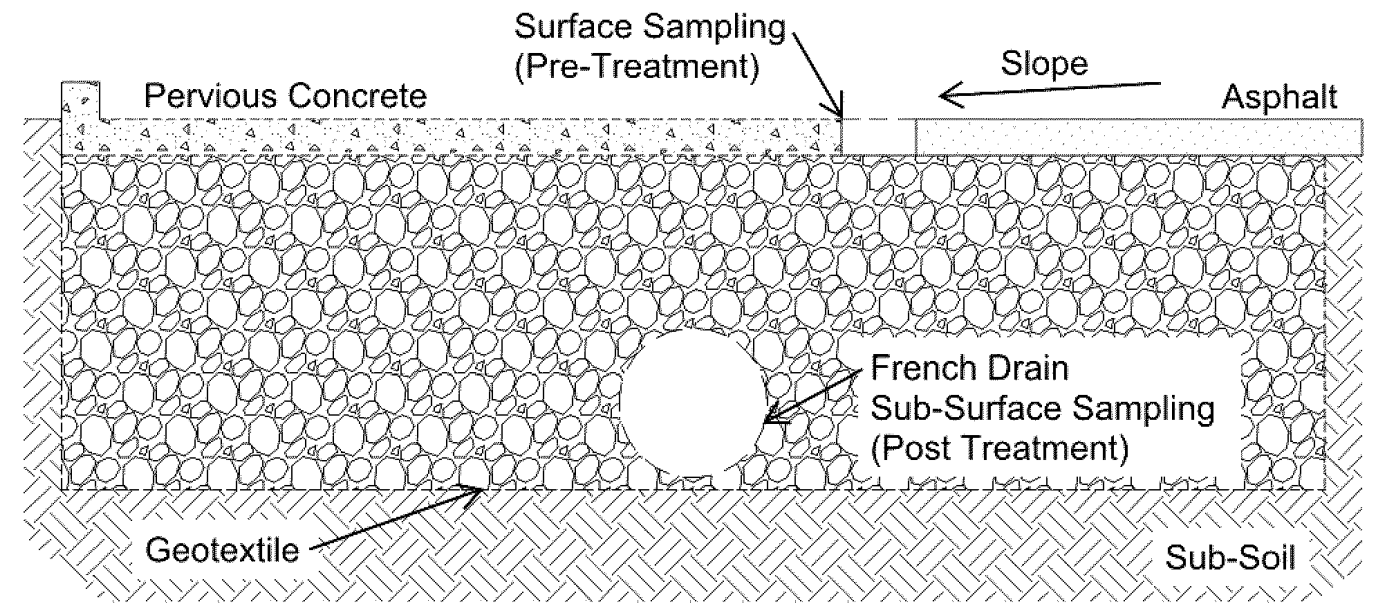

Figure 2. Schematic cross section of the Alcoa pervious pavement site.

\subsection{Sample Collection}

Two solar powered sampling stations were installed adjacent to the parking area to collect samples of the untreated asphalt runoff and the treated pervious concrete discharge (Figure 3). Float switches were installed in both the runoff collection box and the outlet end of the French drain, each triggering a Campbell Scientific (Logan, UT, USA) data logger at that sampling location. The loggers were programmed to check their float switch for the presence of water every $15 \mathrm{~min}$. After detecting water, the loggers turned on ISCO (Lincoln, NE, USA) samplers and treated and untreated samples were collected every $5 \mathrm{~min}$ until all water was removed. Three samples (representing 15 min of stormwater) were placed into each of up to 24 sample bottles, such that a 6-h event could be fully sampled. A Texas Electronics (Dallas, TX, USA) tipping bucket rain gauge connected to the surface data logger recorded the precipitation depth every $15 \mathrm{~min}$.

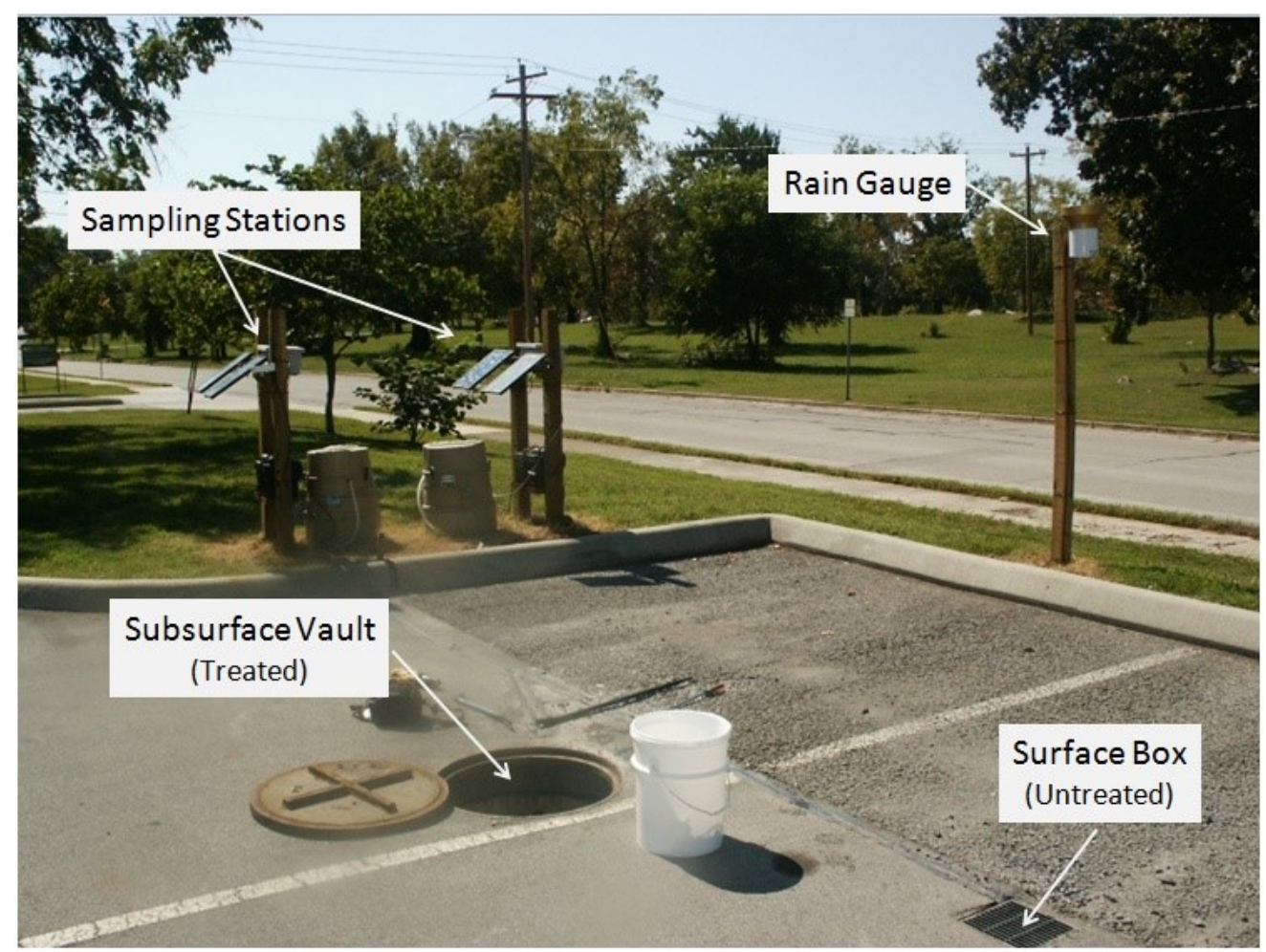

Figure 3. Sampling apparatus installed at site. 


\subsection{Sample Analysis}

After rainfall events, samples were collected from the samplers and transported to the Department of Biosystems Engineering and Soil Science Water Quality Laboratory at the University of Tennessee, where they were refrigerated at $4{ }^{\circ} \mathrm{C}$ until they could be analyzed. Sampling and measurement of stormwater took place from April through September 2009 for five storm events following installation of the sampling system. Both untreated and treated stormwater samples were analyzed for $\mathrm{pH}$, turbidity, total suspended solids, chemical oxygen demand (COD), nitrite, nitrate, and sulfate, lead, zinc, and polycyclic aromatic hydrocarbons (PAHs).

The $\mathrm{pH}$ and turbidity of each stormwater sample was measured with an Orion 525A probe meter (Thermo Electron Corp, Beverly, MA, USA) and a Monitek CST06825 Model 21 Nephelometer (Galvanic Applied Sciences, North Billerica, MA, USA), respectively. Total Suspended Solids (TSS) were measured according to Standard Method 2540 D [29]. Nitrite, nitrate, and sulfate concentrations were measured according to USEPA Method 300.1 [30] using a Dionex DX-100 Ion Chromatograph (IC) (Thermo Fisher Scientific, Waltham, MA, USA) with Fluka (Honeywell International, Inc., Charlotte, NC, USA) brand IC standard solutions used to calibrate the IC prior to measurement. COD was measured rather than BOD due to ease of measurement and the correlation between the two parameters following Standard Method 5220 D [29] using a Hach DR/2010 Spectrophotometer (Hach, Loveland, CO, USA). Lead and zinc concentrations were measured with a Spectro CIROS ICP-OES (Spectro, Kleve, Germany) inductively coupled plasma (ICP) mass spectrometer (MS) using commercially available standards.

PAHs were measured via a multistep process following Standard Method 3510C [29], Separatory Funnel Liquid-Liquid Extraction, and Standard Method 8270D [29], Semivolatile Organic Compounds by Gas Chromatography Mass Spectrometry. A suite of 16 PAHs typically found in used motor oil were analyzed using Restek 8270 Calibration Mix \#5 (Bellefonte, PA, USA) and a Shimadzu GCMS-QP20105/GC-2010 gas chromatograph spectrometer (Shimadzu, Columbia, MD, USA).

\subsection{Statistical Analysis}

A statistical evaluation was completed to compare the pollutant concentrations between the treated and untreated samples. The treated and untreated samples were analyzed as pairs representing the inflow and outflow streams of the pervious concrete area. A one-tailed t-test of the paired data showed whether the means of the data were significantly different, defined as $p<0.05$.

\section{Results and Discussions}

Five large precipitation events from April to September 2009 were sampled and analyzed. Table 1 provides a summary of the storm events, with depths ranging from 19.1 to $117.5 \mathrm{~mm}$ and durations ranging from 2.00 to $18.25 \mathrm{~h}$.

Table 1. Summary of precipitation events sampled.

\begin{tabular}{cccccc}
\hline Variable & $\mathbf{4 / 1 0}$ & $\mathbf{6 / 1 7 - 1 8}$ & $\mathbf{8 / 2 4}$ & $\mathbf{9 / 2 4}$ & $\mathbf{9 / 2 6}$ \\
\hline depth $(\mathrm{mm})$ & 22.4 & 19.1 & 32.8 & 25.2 & 117.5 \\
duration $(\mathrm{hrs})$ & 9.25 & 18.25 & 13.0 & 2.00 & 9.75 \\
average intensity $(\mathrm{mm} / \mathrm{hr})$ & 2.42 & 1.05 & 2.52 & 12.60 & 12.05 \\
\hline
\end{tabular}

The paired samples (untreated versus treated) for each of the nine water quality parameters measured are plotted in Figure 4, which displays box and whisker plots of the treated and untreated samples. 

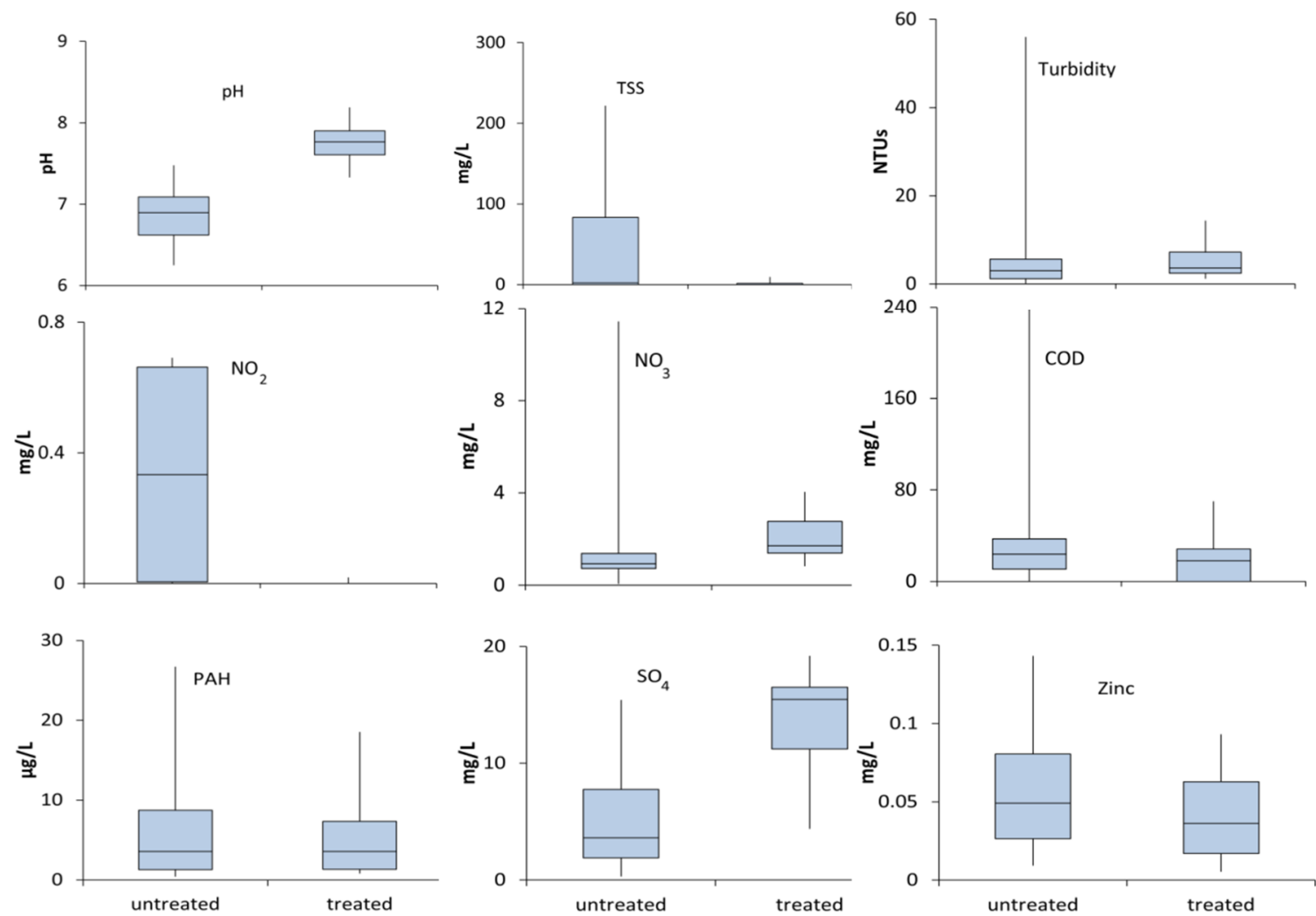

Figure 4. Box plots of the nine types of water quality measurements, for all samples across all events. The upper and lower point on the vertical lines represents the maximum and minimum measured values. The top and bottom of the blue rectangles represent the 1st and 3rd quartiles, with the horizontal line representing the median value.

The mean values for the nine water quality parameters for both the untreated and treated samples are provided in Table 2. Additionally, the differences between the means, percentage change of the means, the number of pairs of samples, and the $p$-values are also provided. Underlined $p$-values represent a significant difference between the means of untreated and treated samples.

Table 2. Summary of measurements and statistical analysis. Underlined $p$-values are significant.

\begin{tabular}{ccccccc}
\hline Measurement & Mean Untreated & Mean Treated & Change & \% Change & $\mathbf{n}$ (Pairs) & $p$ \\
\hline $\mathrm{pH}(-)$ & 6.87 & 7.75 & +0.89 & +12.92 & 76 & $\underline{\leq 0.0001}$ \\
TSS (mg/L) & 54.67 & 1.48 & -53.2 & -97.3 & 9 & $\underline{0.048}$ \\
Turbidity (NTU) & 5.3 & 5.3 & 0 & 0 & 87 & 0.49 \\
Nitrite (mg/L) & 0.338 & 0.004 & -0.334 & -98.8 & 10 & $\underline{0.038}$ \\
Nitrate (mg/L) & 2.03 & 2.05 & +0.02 & +1.0 & 10 & 0.49 \\
COD (mg/L) & 31.4 & 20.0 & -11.4 & -36.2 & 64 & $\underline{0.013}$ \\
PAH ( $\mu$ g/L) & 6.32 & 3.93 & -2.39 & -37.8 & 10 & $\underline{0.027}$ \\
Sulfate (mg/L) & 5.33 & 13.82 & +8.49 & +159 & 10 & $\underline{0.0015}$ \\
Zinc $(\mathrm{mg} / \mathrm{L})$ & 0.0263 & 0.0183 & -0.0081 & -30.6 & 10 & 0.054 \\
\hline
\end{tabular}

The $\mathrm{pH}$ of the discharge from the pervious concrete was slightly basic and significantly higher $(p<0.0001)$ than the runoff from the asphalt parking lot (Figure 4$)$. Given the limestone stone fill beneath the concrete, it follows that the stormwater would become basic after passing through it. The results are consistent with a previous study that showed acidic rain water $(\mathrm{pH}=6.5)$ can become basic ( $\mathrm{pH}=8.0$ ) after passing through limestone aggregate [31].

Total suspended solids were significantly reduced $(p=0.048)$ by the pervious system, with an overall reduction of $97.3 \%$. As sediment entrained within the stormwater enters the system it 
slows and settles. This result is consistent with References [21,23,26,27], while Reference [11] saw no significant change of concentrations. Removal of TSS by a permeable pavement system can lead to clogging, which can be ameliorated [32].

The average turbidity did not change significantly following treatment $(p=0.49)$, although the highest turbidities were reduced to below 14.4 NTUs from a maximum untreated value of 56 NTUs. Both the inlet and outlet mean turbidities were 5.3 NTUs, which is moderately clear stormwater. Conceptually, both the concrete and the stone fill have large surface areas that can serve as trickling filters that trap mineral and biological pollutants which lead to high turbidity, but the size of the material and flowrates though the gravel may have been too fast to allow the very small sized particles most responsible for the minimal turbidity present for most of the samples to settle. Turbidity caused by small particulate matter would explain why the turbidity did not decrease significantly, while the total suspended solids did decrease significantly.

Nitrite is a byproduct of nitrification of ammonia in rainwater and readily reacts to form nitrate under aerobic conditions. Nitrite was significantly $(p=0.038)$ reduced by $98.8 \%$ due to passing stormwater through the system. Nitrifying bacteria convert nitrite within the pervious concrete detention system to nitrate, which is less toxic than the former. Average treated concentrations of nitrate were almost identical to the untreated averages $(p=0.49)$, although the highest concentrations above $10 \mathrm{mg} / \mathrm{L}$ - the EPA's maximum contaminant level for nitrate-were avoided following treatment. Previous studies have shown mixed results related to nitrite and nitrate. One study found no change in either nitrite or nitrate [20], whereas another reported decreases of nitrate [26].

Average sulfate concentrations were significantly higher following treatment $(p=0.0015)$ compared to the asphalt runoff, with increases in sulfate concentration in all but the first event. It is possible that the source of added sulfate in the treated samples came from the degradation of hydrocarbons or other organic content within the treatment system [33]. The sulfate may have also been created by oxidation of another form of sulfur that entered the system, but was not measured such as sulphide.

Treatment caused COD to decrease significantly $(p=0.013)$ by $36.2 \%$. This result is consistent with aerobic conditions and the subsequent oxidation of pollutants and organic material within the treatment system.

Lead was below the detection limits of the Spectro CIROS ICP-OES ICP MS for all samples from both treatments. Zinc concentrations appeared to decrease by $30.6 \%$, but that decrease failed to meet the statistical test of significance $(p=0.054)$. Being a highly retarded pollutant, zinc is readily adsorbed by any available organic material. A reduction of zinc concentration is consistent with previous studies [10,20-24,26,27].

The concentrations of hydrocarbons were significantly lower after treatment $(p<0.01)$. The second storm in September had a hydrocarbon concentration near $45 \mu \mathrm{g} / \mathrm{L}$, which was atypically high in comparison to the other events. It is possible that a vehicle leaked a large quantity of oil or some other fluid prior to this storm event, causing a spike in hydrocarbons.

\section{Conclusions}

Although pervious pavements serve primarily to reduce runoff volumes and peak flow rates by temporarily storing stormwater and increasing infiltration into the underlying soil, this research showed that a pervious concrete detention system is also capable of removing stormwater pollutants. The pervious concrete paving at the Alcoa City Center significantly $(p<0.05)$ reduced the concentrations of TSS, nitrite, COD, and PAH concentrations compared to untreated asphalt runoff. Zinc concentrations were apparently reduced, but not quite to significant levels $(p=0.054)$. The $\mathrm{pH}$ and sulfate both showed significant $(p<0.05)$ increases. These results support the hypothesis that pervious concrete with an underlying limestone base can reduce runoff pollutant loadings and may lead to a wider acceptance of pervious concrete as an alternative to more commonly-used practices (e.g., detention basins that utilize valuable land area) for the purpose of improving the quality of 
stormwater being discharged to surface waters. This would allow developers to incorporate existing infrastructure such as parking lots into their stormwater management plans and to save their clients' money while protecting the environment.

Author Contributions: B.S.P. conducted the field experiments, analyzed the data, and wrote the draft manuscript. D.C.Y. and J.R.B. helped conceptualize the project along with data analysis, validation, and editing. J.S.T. oversaw the overall project and helped with the analysis, writing, and figures.

Funding: The authors would like to thank the funding provided by The University of Tennessee Institute of Agriculture.

Conflicts of Interest: The authors declare no conflict of interest.

\section{References}

1. Hun-Dorris, T. Advances in porous pavement. Stormwater 2005, March-April 2005 URL in press.

2. National Research Council (NRC). Urban Stormwater Management in the United States; National Academies Press: Washington, DC, USA, 2008.

3. Tennis, P.D.; Leming, M.L.; Akers, D.J. Pervious Concrete Pavements; Portland Cement Association: Skokie, IL, USA, 2004.

4. Obla, K.H. Pervious concrete-An overview. Indian Concr. J. 2010, 84, 9-18.

5. Tu, M.C.; Traver, R. Water table fluctuation from green infrastructure sidewalk planters in Philadelphia. J. Irrig. Drain. Eng. 2019, 145, 05018008. [CrossRef]

6. Tu, M.C.; Smith, P. Modelling pollutant buildup and washoff parameters for SWMM based on land use in a semiarid urban watershed. Water Air Soil Pollut. 2018, 229. [CrossRef]

7. USEPA (United States Environmental Protection Agency). Stormwater Phase II Final Rule; Office of Water, USEPA: Washington, DC, USA, 2005.

8. Pitt, R.; Field, R.; Lalor, M.; Brown, M. Urban stormwater toxic pollutants: Assessment, sources, and treatability. Water Environ. Res. 1995, 67, 260-275. [CrossRef]

9. Sartor, J.D.; Boyd, G.B.; Argady, F.J. Water pollution aspects of street surface contaminants. J. Water Pollut. Contorl Fed. 1974, 46, 458-467.

10. Legret, M.; Pagotto, C. Evaluation of pollutant loadings in the runoff waters from a major rural highway. Sci. Total Environ. 1999, 235, 143-150. [CrossRef]

11. USEPA (United States Environmental Protection Agency). National Water Quality Inventory: Report to Congress; Office of Water, USEPA: Washington, DC, USA, 2009.

12. USEPA (United States Environmental Protection Agency). Pervious Concrete Pavement; National Pollutant Discharge Elimination System, USEPA: Washington, DC, USA, 2009.

13. USEPA (United States Environmental Protection Agency). Preliminary Data Summary of Urban Storm Water Best Management Practices; Office of Water, USEPA: Washington, DC, USA, 1999.

14. Motto, H.L.; Daines, R.H.; Chilko, D.M.; Motto, C.K. Lead in soils and plants: Its relationship to traffic volume and proximity to highways. Environ. Sci. Technol. 1970, 4, 231-237. [CrossRef]

15. Lagerwerff, J.V.; Specht, A.W. Contamination of roadside soil and vegetation with cadmium, nickel, lead and zinc. Environ. Sci. Technol. 1970, 4, 583-586. [CrossRef]

16. Chow, T.J. Lead accumulation in roadside soil and grass. Nature 1970, 225, 295-296. [CrossRef]

17. Milberg, R.P.; Lagerwerff, J.V.; Brower, D.L.; Biersdorf, G.T. Soil lead accumulation alongside a newly constructed roadway. J. Environ. Qual. 1980, 9, 6-8. [CrossRef]

18. Pratt, C.J.; Newman, A.P.; Bond, P.C. Mineral oil bio-degradation within a permeable pavement: Long term observations. Water Sci. Technol. 1999, 39, 103-109. [CrossRef]

19. Tota-Mahara, K.; Scholz, M. Efficiency of permeable pavement systems for the removal of urban runoff pollutants under varying environmental conditions. Environ. Prog. Sustain. Energy 2010, 29, 358-369. [CrossRef]

20. Bean, E.Z.; Hunt, W.F.; Bidelspach, D.A. Evaluation of four permeable pavement sites in eastern North Carolina for runoff reduction and water quality impacts. J. Irrig. Drain Eng. 2007, 133, 583-592. [CrossRef]

21. Legret, M.; Colandini, V.; Le Marc, C. Effects of porous pavement with reservoir structure on the quality of runoff water and soil. Sci. Total Environ. 1996, 189-190, 335-340. [CrossRef] 
22. Legret, M.; Colandini, V. Effects of a porous pavement with reservoir structure on runoff water: Water quality and fate of heavy metals. Water Sci. Technol. 1999, 9, 111-117. [CrossRef]

23. Pagotto, C.; Legret, M.; Le Cloirec, P. Comparison of the hydraulic behavior and the quality of highway runoff water according to the type of pavement. Water Res. 2000, 34, 4446-4454. [CrossRef]

24. Booth, D.B.; Leavitt, J. Field evaluation of permeable pavement systems for improved stormwater management. J. Am. Plan. Assoc. 1999, 62, 314-325. [CrossRef]

25. Brattebo, B.O.; Booth, D.B. Long-term stormwater quantity and quality performance of permeable pavement systems. Water Res. 2003, 37, 4369-4376. [CrossRef]

26. Rushton, B.T. Low-impact parking lot design reduces runoff and pollutant loads. J. Water Res. Plan. Manag. 2001, 127, 172-179. [CrossRef]

27. Gilbert, J.K.; Clausen, J.C. Stormwater runoff quality and quantity from asphalt, paver, and crushed stone driveways in Connecticut. Water Res. 2006, 40, 826-832. [CrossRef] [PubMed]

28. Wang, M.; Zhang, D.; Li, Y.; Hou, Q.; Yu, Y.; Qi, J.; Fu, W.; Dong, J.; Cheng, Y. Effect of a submerged zone and carbon source on nutrient and metal removal for stormwater by bioretention cells. Water 2018, 10, 1629. [CrossRef]

29. AWWA (American Water Works Association). Standard Methods for the Examination of Water and Wastewater, 21th ed.; AWWA: Denver, CO, USA, 2005.

30. USEPA (United States Environmental Protection Agency). Method 300.1: Determination of Inorganic Anions in Drinking Water by Ion Chromatography; Revision 1.0.; USEPA: Cincinnati, OH, USA, 1997.

31. Pratt, C.J. Use of permeable, reservoir pavement constructions for stormwater treatment and storage for re-use. Water Sci. Technol. 1999, 39, 145-151. [CrossRef]

32. Seghal, K.; Drake, J.; Seters, T.V.; Linden, W.K.V. Improving restorative maintenance practices for mature permeable interlocking concrete pavements. Water 2018, 10, 1588.

33. Fetter, C.W. Contaminant Hydrogeology, 2nd ed.; Waveland Press, Inc.: Long Grove, IL, USA, 1999.

(C) 2019 by the authors. Licensee MDPI, Basel, Switzerland. This article is an open access article distributed under the terms and conditions of the Creative Commons Attribution (CC BY) license (http:/ / creativecommons.org/licenses/by/4.0/). 